\title{
OPTIMALISASI KEMAMPUAN BERBICARA DENGAN METODE BERCERITA PADA ANAK USIA DINI
}

\author{
Mega Hazwani ${ }^{1}$, Adityawarman ${ }^{2}$, Yolanda Pahrul ${ }^{3}$,Moh.fauziddin ${ }^{4}$ \\ Fakultas Keguruan dan Ilmu Pendidikan, Universitas Pahlawan ${ }^{1,2,3,4}$ \\ Email: megahazwani27@gmail.com¹, adityawarmanhidayat89@gmail.com², \\ yolandapahrul@gmail.com ${ }^{3}$, mfauziddin@gmail.com ${ }^{4}$ \\ Hazwani, Mega., Adityawarman, Yolanda Pahrul, Moh Fauziddin. (2021). Meningkatkan Kemampuan \\ Berbicara Anak Memalui Metode Bercerita Kelompok B Usia 5-6 Tahun di TK Plamboyan Mekar. \\ Jurnal Pelita PAUD.6(1), 135-140. \\ doi : https://doi.org/10.33222/pelitapaud.v6i1.1424
}

Diterima:25-08-2021

Disetujui: $31-08-2021$

Dipublikasikan: 26-12-2021

\begin{abstract}
Abstrak: Penelitian ini bertujuan untuk mengetahui peningkatan kemampuan berbicara anak.Kegiatan berbicara menggunakan media gambar yang bervariasi sehingga mampu memotivasi minat anak. Jenis penelitian dilakukan secara kolaboratif dengan model Kemmis \& Mc Taggart. Setiap siklus terdiri dari empat tahap yaitu perencanaan, pelaksanaan, pengamatan, dan refleksi.Objek penelitian adalah kemampuan berbicara melalui media gambar.Teknik pengumpulan data menggunakan observasi, dokumentasi, dan wawancara.Instrumen yang digunakan dalam observasi berupa lembar penilaian, untuk dokumentasi menggunakan kamera, dan wawancara menggunakan pedoman wawancara dengan guru.Teknik analisis data yang digunakan adalah deskriptif kuantitatif dan deskriptif kualitatif.Hasil penelitian ini menunjukkan adanya peningkatan kemampuan berbicara anak melalui media gambar di TK Plamboyan Mekar. Hal ini dibuktikan dengan adanya peningkatan rata-rata kemampuan berbicara anak pada Pratindakan sebesar 38,18\%, meningkat menjadi 54\% pada tindakan Siklus I, dan mencapai $84,18 \%$ pada tindakan Siklus II. Kemampuan berbicara anak mengalami peningkatan setelah peneliti memberikan tindakan yang dilakukan melalui beberapa tahapan dan proses.
\end{abstract}

Kata kunci: Kemampuan Berbicara, Metode bercerita, Media Gambar

Abstract : This study aims to determine the improvement of children's speaking ability. Talking activities use a variety of picture media so that they can motivate children's interests. This type of research is carried out collaboratively with the Kemmis \& Mc Taggart model. Each cycle consists of four stages, namely planning, implementation, observation, and reflection. The object of research is the ability to speak through the media of images. Data collection techniques using observation, documentation, and interviews. The instrument used in the observation was in the form of an assessment sheet, for documentation using a camera, and interviews using an interview guide with the teacher. The data analysis technique used is descriptive quantitative and descriptive qualitative. The results of this study indicate an increase in children's speaking skills through picture media in Plamboyan Mekar Kindergarten. This is evidenced by an increase in the average speaking ability of children in the Pre-action by $38.18 \%$, increasing to 54\% in the Cycle I action, and reaching $84.18 \%$ in the Cycle II action. The child's speaking ability has increased after the researcher provides actions that are carried out through several stages and processes.

Keywords:Speaking ability, Storytelling method, Image media

http://jurnal.upmk.ac.id/index.php/pelitapaud 


\section{PENDAHULUAN}

Pengolahan data penelitian diperoleh hasil pertama bahwa dengan menggunakan metode bercerita dapat meningkatkan kemampuan berbicara anak, ketika anak berbicara bahkan didepan kelas, ketika akan menyampaikan apa yang dipikirannya sembari mengekspresikannya. Metode bercerita yang menarik dapat membuat anak memperhatikan cerita serta anak dapat memahami apa yang hendak disampaikanmelalui cerita tersebut. Sehingga anakanak tidak menjadi jenuh, bahkan dapat menjadikan pembelajaran yang sangat menyenangkan bagi anak(Oktari et al, 2013).

Berdasarkan hasil observasi yang dilakukan di TK Plamboyan Mekar Desa Tanjung Sawit Kecamatan Tapung Kabupaten Kampar pada kelompok B 5-6 tahun dengan jumlah 17 anak terdiri dari 12 anak perempuan dan 5 anak laki-laki. Keadaan awal pada kelas tersebut banyak sekali permasalahan dalam perkembangan berbicara antara lain anak yang. Berdasarkan data tersebut anak masih mengalami kesulitan dalam berbicara seperti ada anak yang susah untuk diajak berkomunikasi atau bisa dikatakan lambat untuk menjawab pertanyaan yang diberi oleh gurunya (lambat merespon pertanyaan), ada anak yang kemampuan berbicaranya kurang jelas cara pengucapannya, dan ada anak yang pendiam serta jarang berbicara dengan guru ataupun teman-temannya. Anak tidak dapat menceritakan pengalamannya dikarenakan kemampuan berbicara anak tidak lancar. Hal ini terlihat pada saat anak mencoba menceritakan pengalaman didepan kelas, anak-anak masih bingung dengan kata-kata yang akan diucapkan, sehingga anak menjadi kurang percaya diri bila berbicara didepan teman-temannya. Kebingungan atau ketidakmampuan anak dalam berbicara disebabkan karena bahasa yang digunakan masih kurang jelas artikulasinya dan belum berbicara dengan kalimat lengkap.Dilihat dari pengamatan menunjukkan bahwa sebagian anak masih rendah kemampuan berbicaranya, terutama bahasa lisannya hal ini terlihat anak belum mampu menyebutkan kembali 4-5 kata. Disamping itu, anak belum dapat menyebutkan benda-benda yang disekitarnya, ketika bercerita dan berbicara dengan teman-temannya untuk tampil di depan kelas terlihat sangat minim anak yang berani menunjukkan kemampuan berbicara di depan teman-temannya.Keterbatasan anak dalam mengungkapkan lisannya dikelas dikarenakan metode yang digunakan guru belum tepat dan belum sesuai dalam menstimulus perkembangan bahasa anak. Salah satu dari beberapa tahap tersebut memiliki peranan yang sangat penting adalah berbicara dan komunikasi, karena dengan berbicara anak bisa menyampaikan maksud dan tujuan kepada teman, guru, orang tua dan sebagainya. Oleh sebab itu, bahasa perlu diajarkan atau ditanamkan sejak dini kepada anak. Salah satu kemampuan bahasa menyatakan bahwa bentuk bahasa yaitu: menyimak, berbicara, membaca, dan menulis. Berbicara merupakan kemampuan yang perlu dipelajari untuk anak usia dini sebagai kegiatan penting bersosialisasi. Berbicara memiliki beberapa fungsi diantaranya: pengucapan kata, pengembangan kosa kata, pembentukan kalimat. Pembentukan kalimat merupakan tugas ketiga belajar berbicara dalam perkembangan anak usia dini yang sangat penting. Salah satu cerita yang digunakan dalam penerapan pembelajaran dengan menggunakan metode storytelling adalah cerita rakyat. Cerita rakyat ini merupakan cerita yang dapat digunakan dalam penerapan metode storytelling. Meskipun begitu cerita rakyat lainnya dapat juga digunakan sebagai obyek kegiatan pembelajaran. Penanaman nilai-nilai karakter dengan metode storytelling menggunakan cerita rakyat suku sebagai pengenalan nilai lokal kepada anak. (Haerudin, 2018).

Terkait dengan berbagi masalah tersebut, adanya upaya perbaikan dalam pengembangan kemampuan berbicara anak. Upaya yang dilakukan pendidik atau guru untuk peningkatan kemampuan berbicara adalah melalui metode bercerita yang menarik agar menyenangkan pembelajaran bagi anak. Dengan adanya kegiatan ini dapat melatih kosa kata anak dalam berbicara. Metode bercerita merupakan salah satu pemberian pengalaman belajar dengan cerita. Melalui metode bercerita anak mendapat pengalaman serta pengetahuan yang akan disampaikan melalui cerita secara lisan. Selain itu metode bercerita dapat membantu anak dalam mengembangkan dan melatih kemampuan bicara 
anak yang dimiliki. Metode bercerita dapat berpengaruh terhadap kemampuan kosakata anak. Metode bercerita disampaikan melalui cerita yang menarik dengan beberapa macam teknik bercerita yang dipergunakan antara lain; Guru dapat membaca langsung dari buku, menggunakan ilustrasi dari gambar dan bermain peran dalam suatu cerita. Cerita yang disampaikan harus mengandung pesan, nasehat, dan informasi yang ditangkap oleh anak sehingga dapat memahami cerita serta meneladani hal-hal baik yang disampaikan. Metode bercerita dapat berpengaruh terhadap kemampuan berbicara anak karena dengan cerita yang dikemas dan disajikan secara menarik, anak akan memiliki ketertarikan terhadap kelanjutan cerita yang diberikan. Sehingga akan terjadi timbal balik antara pesan yang telah disampaikan oleh guru dalam bentuk cerita dengan apa yang diterima oleh anak (Hajrah, 2018). Dari masalah diatas tentang kurangnya kemampuan berbicara anak dapat menyimpulkan pertanyaan mengapa anak-anak belum mampu berbicara dengan baik. Dari kondisi tersebut sudah selayaknya seorang guru PAUD untuk melakukan usaha perbaikan, salah satu usaha yang dapat dilakukan guru adalah memilih salah satu strategi pembelajaran yang tepat. Berdasarkan kesimpulan penelitian terdahulu di atas maka dengan menggunakan metode bercerita lebih berpengaruh terhadap kemampuan berbicara anak. Metode bercerita melibatkan beberapa anak untuk bercerita dan mengungkapkan pendapatnya. Selain untuk meningkatkan kemampuan berbiacara anak, hal tersebut juga meningkatkan rasa percaya diri saat berbicara didepan kelas.

\section{METODE PENELITIAN}

\section{Jenis Penelitian}

Jenis penelitian yang digunakan yaitu PTK Penelitian Tindakan Kelas (classroom action reaserch).Arikunto, (2014:58) mengatakan bahwa PTK bertujuan dengan memperbaiki mutu praktik pembelajaran dikelas.

\section{Waktu dan Tempat Penelitian}

Penelitian ini menganalisis cara peningkatan kemampuan berbicara anak melalui metode berbicara di TK Plamboyan Mekar dikelas B3 usia 5-6 Tahun dengan jumlah 17 anak. Penelitian ini dilaksanakan pada semester II tahun ajaran 2020/2021 yaitu pada bulan Mei 2021.

\section{Prosedur}

Peneliti merencanakan tindakan dengan dua siklus dan setiap siklus terdiri dari tiga pertemuan, setiap siklusnya sesuai prosedur yang ditentukan. Masingmasing siklus terdiri dari empat komponen yaitu, perencanan, pelaksanaan, observasi, refleksi. Pada siklus ini peneliti menetapkan indikator keberhasilan berdasarkan permasalahan yang sedang diteliti tentang kemampuan berbicara anak.

Data, Intrumen, dan Teknik Pengumpulan Data Jenis instrument yang digunakan sebagai alat pengambilan data dalam penelitian tindakan ini adalah instrumen yang mengacu pada kemampuan berbicara anak usia 5-6 tahun dengan teknik observasi melalui catatan observasi awal. Instrumen dikembangkan dalam bentuk ceklis dengan rentan skor 1-4.

\section{Teknik Analisis Data}

Penelitian ini termasuk penelitian kuantitatif dan penelitian kualitatif.Secara kuantitatif data yang terkumpul dianalisa secara deskriptif persentase.Jumlah anak yang mampu mencapai indikator keberhasilan dibagi jumlah seluruh anak yang diteliti dikalikan 100\%, maka diketahui persentase dari tingkat keberhasilan tindakan. Indikator penilaian pada kemampuan berbicara anak meliputi: (1). Keberanian dalam bertanya dan menjawab. (2). Kelancaran dalam menyampaikan pendapat. (3). Artikulasi kosa kata yang jelas. (4). Berbicara dengan kalimat lengkap.

\section{HASIL DAN PEMBAHASAN}

Hasil penelitian menunjukkan bahwa melalui kegiatan metode bercerita dapat meningkatkan kemampuan berbicara anak usia dini pada kelompok B TK Plamboyan Mekar. Hasil penelitian dan pembahasan sebagai berikut: kegiatan pembelajaran yang diberikan guru khusus nya tentang kemampuan berbicara anak usai dini yaitu menggunakan metode bercakap-cakap saja tanpa melibatkan murid. Hasil observasi dapat diketahui bahwa kemampuan berbicara anak masih rendah. Terbukti pada data tersebut : 


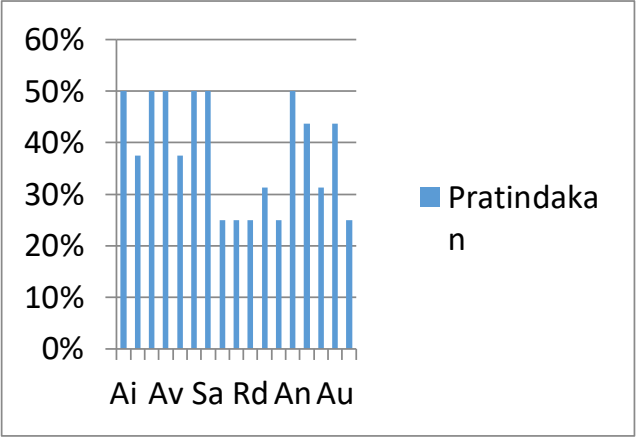

Gambar 1. Rekapitulasi pratindakan

Rekapitulasi dari data diatas menunjukkan bahwa pada skor rata-rata terdapat $38,18 \%$. Hal ini menunjukkan bahwa kemampuan anak masih rendah. Hal ini dapat dilihat berdasarkan table 4.1 yaitu. Ai 50\%, Je 37,5\%, Sal 50\%, Av 50\%, Al 37,5\%, Nu 50\%, Sa 50\%, Ju 25\%, Rf 25\%, Rd 25\%, Di 31,25\%, Rif 25\%, An 50\%, Mi 43,75\%, Pu 31,25\%, Au 43,75\%, Av $25 \%$. Sedangkan rata-rata persentase akhir sekitar $38,18 \%$ Dengan hasil observasi tersebut menunjukkan bahwa kemampuan berbicara anak masih rendah dan belum berkembang dengan baik.

Pada siklus I menyusun perencanaan RPPH yang akan digunakan sebagai acuan dalam pelaksanaan pembelajaran.

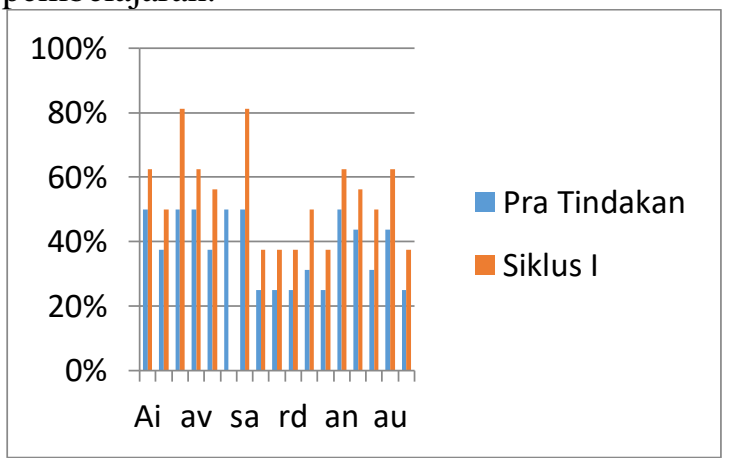

Gambar 2. Rekapitulasi data kemampuan berbicara anak pada siklus I.

Visualisasi grafik menunjukkan peningkatan kemampuan berbicara anak keseluruhan secara merata yang dialami siklus I. Dari peningkatan tersebut hanya 2 (dua) anak yang mencapai skor persentase $\quad 75 \% \quad$ (TCP/tingkat capaian perkembangan), Yaitu Sal 81,25\%, Sa 81,25\% dengan kata lain hanya 2 orang siswa yang mencapai peningkatan sesuai TCP sebesar $75 \%$ dengan criteria menurut mills sebesar $71 \%$. Oleh sebab itu perlu tindakan selanjutnya pada siklus berikutnya.

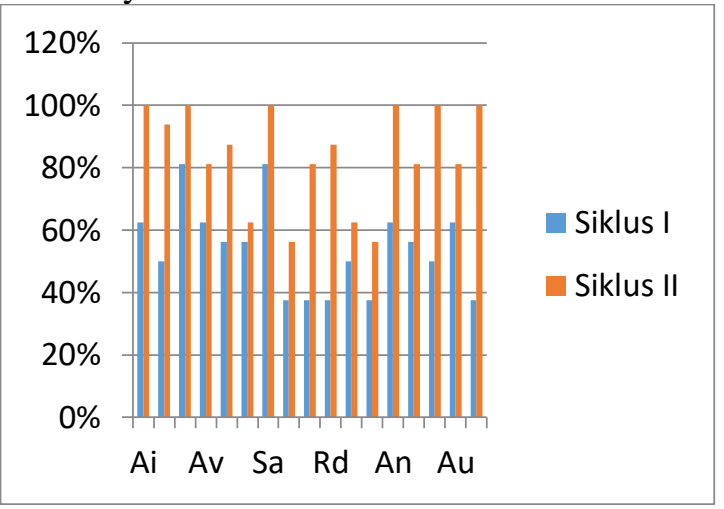

Gambar 3.Rekapitulasi data kemampuan berbicara anak pada siklus II.

Visualisasi grafik menunjukkan peningkatan kemampuan berbicara anak usia 5-6 tahun keseluruhan secara merata yang dialami siklus II. Hal itu terlihat dari anak yang sudah berani dalam berbicara, kelancaran dalam berbicara, berbicara dengan artikulasi yang jelas dan sudah mampu berbicara dengan kalimat lengkap, Dari data pra tindakan menunjukkan skor awal sebagai berikut : dengan rata-rata 6,11 dengan demikian data yang menunjukkan kemampuan berbicara anak TK Plamboyan Mekar pada kelompok B pada siklus II yang memliki skor dengan keterangan berkembang sangat baik ada 13 orang anak, sedangkan yang memiliki skor dengan keterangan berkembang sesuai harapan ada 4 orang anak yaitu $\mathrm{Nu}, \mathrm{Di}$, Rif dan Ju. Adapun persentase tertinggi dari keseluruhan aspek nilai siklus II kemampuan berbicara dimiliki Ai, Sal, Sa, An, Pu sebesar 100\%. Pada tindakan Siklus I terjadi peningkatan, tetapi kurang signifikan karena masih terdapat kendala yang menyebabkan peningkatan kemampuan berbicara melalui media gambar belum maksimal, sehingga diperlukan adanya perbaikan tindakan pada Siklus II yaitu peneliti mengganti gambar 
yang sebelumnya menggunakan gambar buatan sendiri diubah menjadi gambar hasil dari download di internet. Selain itu merubah anak yang duduk dalam kelompok dan menambah alokasi waktu. Peneliti memberikan motivasi berupa pujian dan semangat supaya kegiatan menjadi lebih kondusif dan anak fokus dalam mengikuti. Hal ini diharapkan mampu meningkatkan kemampuan anak dalam berbicara. Setelah terjadi perbaikan tindakan, maka persentase peningkatan kemampuan berbicara anak memalui media gambar sudah signifikan. Terdapat anak yang kemampuan berbicaranya kurang jelas cara pengucapannya , dan ada anak yang pendiam serta jarang berbicara dengan guru ataupun teman-temannya. Anak tidak dapat menceritakan pengalamannya dikarenakan kemampuan berbicara anak tidak lancar. Hal ini terlihat pada saat anak mencoba menceritakan pengalaman didepan kelas, anak-anak masih bingung dengan kata-kata yang akan diucapkan, sehingga anak menjadi kurang percaya diri bila berbicara didepan teman-temannya. Kebingungan atau ketidakmampuan anak dalam berbicara disebabkan karena bahasa yang digunakan masih kurang jelas artikulasinya dan belum berbicara dengan kalimat lengkap.Dilihat dari pengamatan menunjukkan bahwa sebagian anak masih rendah kemampuan berbicaranya, terutama bahasa lisannya hal ini terlihat anak belum mampu menyebutkan kembali 4-5 kata. Disamping itu, anak belum dapat menyebutkan benda-benda yang disekitarnya, ketika bercerita dan berbicara dengan teman-temannya untuk tampil di depan kelas terlihat sangat minim anak yang berani menunjukkan kemampuan berbicara di depan teman-temannya. Keterbatasan anak dalam mengungkapkan lisannya dikelas dikarenakan metode yang digunakan guru belum tepat dan belum sesuai dalam menstimulus perkembangan bahasa anak. Salah satu dari beberapa tahap tersebut memiliki peranan yang sangat penting adalah berbicara dan komunikasi, karena dengan berbicara anak bisa menyampaikan maksud dan tujuan kepada teman, guru, orang tua dan sebagainya. Oleh sebab itu, bahasa perlu diajarkan atau ditanamkan sejak dini kepada anak. Salah satu kemampuan bahasa menyatakan bahwa bentuk bahasa yaitu: menyimak, berbicara, membaca, dan menulis. Berbicara merupakan kemampuan yang perlu dipelajari untuk anak usia dini sebagai kegiatan penting bersosialisasi. Berbicara memiliki beberapa fungsi diantaranya: pengucapan kata, pengembangan kosa kata, pembentukan kalimat. Pembentukan kalimat merupakan tugas ketiga belajar berbicara dalam perkembangan anak usia dini yang sangat penting. Salah satu cerita yang digunakan dalam penerapan pembelajaran dengan menggunakan metode storytelling adalah cerita rakyat. Cerita rakyat ini merupakan cerita yang dapat digunakan dalam penerapan metode storytelling. Meskipun begitu cerita rakyat lainnya dapat juga digunakan sebagai obyek kegiatan pembelajaran. Penanaman nilai-nilai karakter dengan metode storytelling menggunakan cerita rakyat suku sebagai pengenalan nilai lokal kepada anak.(Haerudin, 2018)

Berdasarkan pembahasan di atas hasil kegiatan berbicara melalui media gambar, kemampuan berbicara anak kelompok B di TK Bener Plamboyan Mekar dapat dikatakan meningkat dengan baik. Hal ini sesuai dalam (Nurjanah \& Anggraini, 2020) dengan judul "Metode Bercerita Untuk Meningkatkan Kemampuan Berbicara Anak Pada Usia 5-6 tahun" Hasil penelitian menunjukkan dengan metode bercerita mampu meningkatkan kemampuan berbicara anak dan mengembangkan rasa percaya diri pada anak. Maka dari itu, disarankan kepada guru dalam meningkatkan kemampuan berbicara anak dapat menggunakan metode bercerita dengan melibatkan anak secara langsung. Kegiatan yang digunakan untuk menstimulasi kemampuan berbicara anak Kelompok B TK Plamboyan Mekar adalah berbicara melalui media gambar. Hal ini penelitian dari (Hasanah et al., 2019) juga dapat dilihat relevan dengan judul "Meningkatkan Kemampuan Berbicara Melalui Kegitan Bercerita Berbantu Media Finger Puppet pada Anak TK Kelompok B "penelitian ini membuktikan Kemampuan berbicara dikatakan berhasil apabila 80\% dari 26 jumlah anak telah mencapai indikator kemampuan berbicara pada kriteria berkembang sesuai harapan (BSH). Kegiatan pembelajaran yang baik dalam penerapan pembelajaran di Taman KanakKanak 
adalah kegiatan pembelajaran yang merangsang rasa ingin tahu anak, motivasi anak, intelegensi anak, dan juga kesukaan anak. Salah satu kegiatan pembelajaran adalah dengan menggunakan metode Storytelling.

\section{SIMPULAN}

Penelitian tindakan kelas tentang kemampuan berbicara anak pada kelompok B TK Plamboyan Mekar telah dilaksanakan dalam dua siklus kegiatan, berdasarkan data dan hasil penelitian diatas, maka dapat disimpulkan bahwa ditunjukkan dari meningkatnya hasil pembelajaran dari anak melalui persentase data pra siklus yaitu $38,18 \%$ dari 17 anak. Siklus I sebesar 54\% dari seluruh anak dan pada siklus II sudah mencapai indikitor keberhasilan yaitu $84,18 \%$. Setelah diterapkannya metode berbicara pada anak kelompok B TK Plamboyan Mekar bahwa kemampuan berbicara anak mengalami peningkatan. Hal tersebut dapat dilihat dari hasil peningkatan pada tindakan siklus. Sehingga metode bercerita diterapkan untuk meningkatkan kemampuan berbicara anak. Metode bercerita mampu meningkatkan kemampuan berbicara anak dan mengembangkan rasa percaya diri pada anak. Maka dari itu, disarankan kepada guru dalam meningkatkan kemampuan berbicara anak dapat menggunakan metode bercerita dengan melibatkan anak secara langsung

\section{DAFTAR PUSTAKA}

Alfin, J., Rosyidi, Z., \& Abdillah, H. (2018). Pengembangan Kemampuan Berbicara Bahasa Indonesia Anak Umur 5-6 Tahun Melalui Metode Bercerita Dengan Media Televisi Bergambar. JPUD - Jurnal Pendidikan Usia Dini, 12(2), 271280. https://doi.org/10.21009/jpud.122.08

Farida, T., \& Rosidah, L. (2018). Meningkatkan Kemampuan Berbicara Anak Usia 5-6 Tahun Melalui Metode Bermain Peran. Jurnal Penelitian Dan Pengembangan Pendidikan Anak Usia Dini, 5(2), 143. https://doi.org/10.30870/jpppaud.v5i2.4702

Febiola, S., \& Yulsyofriend. (2020). Penggunaan Media Flash Card terhadap Kemampuan Berbicara Anak Usia Dini. Jurnal Pendidikan Tambusai, 4(2), 1026-1036.
Hajrah. (2018). Pengembangan Metode Bercerita Pada Anak Usia Dini. Administrasi Pendidikan Kekhususan PAUD, 1, 1-14.

Hasanah, N., Harmawati, D., \& Hidayat, A. K. (2019). Meningkatkan Kemampuan Berbicara melalui Kegiatan Bercerita Berbantu Media Finger Puppet pada Anak Kelompok B. Musamus Journal of Primary Education, 2(1), 32-37. https://doi.org/10.35724/musjpe.v2i1.2046

Helmi Rahma Wati, \& Yulsyofriend. (2019). Stimulasi Kemampuan Berbicara Anak di PAUD Solok Selatan Sejahtera. Golden Age: Jurnal Ilmiah Tumbuh Kembang Anak Usia Dini, 4(2), 51-60. https://doi.org/10.14421/jga.2019.42-05

Hemah, E., Sayekti, T., \& Atikah, C. (2018). Meningkatkan Kemampuan Bahasa Anak Melalui Metode Bercerita Pada Anak Usia 5-6 Tahun. Jurnal Penelitian Dan Pengembangan Pendidikan Anak Usia Dini, 5(1), 1. https://doi.org/10.30870/jpppaud.v5i1.4675

Istiarini, R. (2014). Peningkatan kemampuan berbicara melalui bermain balok. Pendidikan Usia Dini, $8(1), 1-9$.

Lestari, I. (2018). Analisis Awal Kemampuan Bercerita Pada Anak Usia 5 - 6 Tahun. JIV-Jurnal Ilmiah Visi, 13(2), 165-177. https://doi.org/10.21009/jiv.1302.10

Nurjanah, A. P., \& Anggraini, G. (2020). Metode Bercerita Untuk Meningkatkan Kemampuan Berbicara Pada Anak Usia 5-6 Tahun. Jurnal Ilmiah Potensia, 5(1), 1-7.

oktari, richa, -, F., \& -, H. (2013). Penerapan Metode Bercerita Pada Anak Usia 5-6 Tahun Di Tk Kemala Bhayangkari 14. Jurnal Pendidikan Dan Pembelajaran, 2(4), 1-12.

Program, J., Pendidikan, S., \& Usia, A. (2017). Upaya Meningkatkan Kemampuan Berbicara Melalui Metode Tanya Jawab Pada Anak Usia 4 - 5 Tahun. 6(1), 1-15.

Ratnasari, E. M., \& Zubaidah, E. (2017). Pengaruh Penggunaan Buku Cerita Bergambar Terhadap Kemampuan Berbicara Anak. 9(3), 267-275.

Sunaryanto, M. (2015). Upaya Meningkatkan Kemampuan Berbicara Anak Usia 5-6 Tahun Dengan Media Poster Di Tk Aba Wonotingal Poncosari Srandakan Bantul Yogyakarta. Http://Journal.Student.Uny.Ac.Id/Ojs/Index.Php/ Pgpaud/Article/View/320.

Suradinata, N. I., \& Maharani, E. A. (2020). Pengaruh Bercerita Berbantuan Media Boneka Tangan terhadap Kemampuan Berbicara Anak. Journal on 
P ISSN 2548-6284E ISSN 2615-0360

Vol. 6 No. 1 Desember 2021
Early Childhood Education Research (JOECHER),

1(2),

72-81.

https://doi.org/10.37985/joecher.v1i2.11

Suryana, D., \& Dewi, R. A. (2013). Pengembangan

Kemampuan Berbicara Melalui Metode Bermain

Peran Pada Anak Usia 4-5 Tahun Speaking Ability
Development Through Role-Play Methods In Children At 4-5 Years Old. 